\title{
Political Islam and the future of Australian multiculturalism
}

\author{
Andrew Jakubowicz ${ }^{1}$
}

\section{Keywords: Islam, Australia, multiculturalism, polity, integration}

\begin{abstract}
How can complex and diverse societies ensure the survival of core democratic values and the allegiance of all citizens, while respecting cultural difference? In the Australian context, these issues have been foregrounded by the presence of Muslim communities. This paper argues that the discourses about Muslims and discourses by Muslims can work to reveal the dynamics for negotiating social cohesion. The political projects of mainstream Muslim communities can play a critical role in knitting together fragmented elements, and offering broader fronts through which a more integrated multicultural society can evolve. However, the potential for integration can be undermined in two ways: a) by political decisions in the dominant society that reject such projects, rather than engaging with them in creative and constructive directions, and b) by marginal groups within Muslim communities gaining greater leverage over younger people in a period of heightened apprehension occasioned by world events and Australian government reactions.
\end{abstract}

Like Christians, Muslims come from different groups - Sunni, Alawi, Shiite, Druze and numerous other creeds. Like Christians, they can be secular. Like Christians, not all go to weekly worship. Like Christians, they do not look up to one leader. (Joseph Wakim, Australian Arabic Council, Sydney Morning Herald, 14 September 2005).

I believe that Islam is a positive contribution to Australian life. It is the strongest support to multiculturalism in Australia...We hope that one day Australian Muslims will represent political Islam in Australia. (Sheik Taj Al-Hilaly, Mufti of Australia, Sydney Morning Herald, 11 May 1993).

\section{Introduction}

The growing debates in Australia about the place of Muslims in modern society have been intensified by what one senior journalist has described as the 'third shock' - the bombings in London in July 2005 that followed bombings in Bali of 2002 and the New York and Washington attacks of 2001. The debates are deeply rooted in Australian history and are not simply the consequence of the local reaction to global events. Yet while some sense of the history of Islam and Australia is important, the reality of current policy controversies brings together many streams of contemporary political transformations in Australia - the reassertion of Christian values and institutions in national government; the sustained impact of

\footnotetext{
${ }^{1}$ Professor of Sociology, University of Technology Sydney PO Box 123, Broadway NSW 2007 Australia e: A.Jakubowicz@uts.edu.au
} 
neo-liberal strategies on the social provision of services; and the questioning by neoconservatives of multiculturalism and government-promoted socio-cultural interventions (Jakubowicz, 2005, 2006).

This article explores the diversity of Australian Muslims within an historico-social framework, and then examines how Australian modernity has handled the apparent contradictions that the rising number of Muslims has created for a polity based, as one conservative federal government Minister has avowed, on 'Judaeo-Christian values'. Implicit in this dichotomy appears a discourse of assimilationism, which sits uncomfortably with other claims by governments to espouse 'multiculturalism' - a term finally removed from the institutional designation of the key federal government department in January 2007, to be replaced by "citizenship” as the operant concept. In effect, cultural conflicts are less the case than competition between communities for access to scarce resources in urban environments. The discourses of a cultural clash can be more usefully understood as ideological exercises in social control, famously articulated by a conservative politician as overcoming a 'politics of defiance'. In essence, I am proposing that political Islam has as much or as little a place in secular modernity as political Christianity or political Judaism - that is, a place in which religion and the secular state reach an accommodation that enables both but threatens neither.

\section{Background}

Over the past two decades, the presence of members of the Islamic Ummah (global community) within Australia has risen in public awareness. The history stretches back well before this recent period, and well before European conquest in the late eighteenth century. It is feasible that ships from the fleet of Chinese Muslim eunuch admiral Zheng He reached Australia's north coast in the fifteenth century C.E. Macassan trepang gatherers were trading with the Indigenous peoples of the north by the mid-eighteenth century (their coastal seasonal settlements and occasional inter-marriage with local people providing grist to the mill of those who would see northern Australia as legitimately part of Islam).

Muslim Afghans, Pushtu and Dari speakers from the North Western provinces of British India had been brought to Australia in the mid-nineteenth century as cameleers in support of European exploration and communication (Jones and Museum of Victoria, 1993) - as the community grew it included Durranie Afghans, Tareen Afghans, Pishorie Afghans, Punjabi Indians, and Bengali Indians (Nebhan, 1999). Their camps were known as 'ghans', shortened from Afghan, and their graves can be found along the line of the railway that a century or more later was named after them. Some also settled in Western Australia and built mosques there. Their descendants still live among the Aboriginal communities of the centre, and their attempts to build an Islamic Ummah within an Australian nationalist discourse are recorded in books published by them in the first few decades of last century (Nebhan, 1999).

As with many issues of empire, Australian society has a complex and unresolved relationship with its Muslim history and populations. The Macassan trepangers who had been trading with Northern Australian Aborigines since well before the Europeans arrived, were blocked and then banned by White Australia after centuries of contact, in 1906. Their descendants are still harassed and arrested when their fishing boats enter Australian waters (far extended in the north), to catch food within what had been their fishing space for all memory. Twenty percent of the population of the first part of Australia to be excised in September 2001 from the Migration Zone, Christmas Island, were Malay Muslims - with the majority of the 
remainder Chinese. There are other stories of exclusion and oppression - of Albanians, Turks, and Lebanese (Saeed, 2001; 2003).

\section{Muslim immigration to Australia}

While there was a Muslim presence in Australia throughout the late nineteenth and the early twentieth centuries, the rapid growth in Muslim communities followed three different types of decisions regarding population and national interest in the 1960s and 1970s. The first decision reflected the move to end White Australia policies and the related assumption that such a move would allow Australia to accept members of the global professional classes - doctors, engineers, academics and business people - some of whom would be 'modern' Muslims. The second decision reflected the immigration crises of the 1960s, and the need to replace the working class immigrants of the 1950s who were returning to their European countries of origin, with other industrial workers - often Muslim Turks. The third decision reflected Australia's humanitarian policy commitment, and the response to pressures to admit refugees from the Lebanese civil war, other Middle East conflagrations, and the Balkan wars during and after the mid-1970s.

Together, there decisions created a Muslim population of immigrants and their descendants that (as declared in the 2001 Census) numbered some 280,000, or 1.5 per cent of the total population (up from 200,000 or 1.1 per cent in 1996 and 147500 or 0.9 per cent in 1991). Newspaper stories vary - some claiming up to 450,000 Muslims when reporting some community leaders (The Australian, 17 September 2001).

While Muslims come from over sixty national backgrounds, the two largest groups are the Lebanese and Turks, most of whom are working class and concentrated in quite tight pockets in south western and western Sydney, and in parts of Melbourne. The Muslim population rose some 40 per cent between 1996 and 2001 (the latest Census years); some ethnic groups rose rather more rapidly than this while others remained stable. The most significant increases took place at either ends of the economic ladder - impoverished refugees and well-off professionals and business people. The most significant group of Muslims now are those born in Australia, who contributed about 50 per cent of the increase. Many of them are the children of the two largest communities, while some are converts (or reverts as they are sometimes known in Islam). 
Table 1: Muslims by birthplace, Australia, 2001

Birthplace Australia Percentage all Muslims

Muslims

$\begin{array}{lcc}\text { Australia } & 102566 & 36.43 \\ \text { Afghanistan } & 9923 & 3.52 \\ \text { Bangladesh } & 7596 & 2.70 \\ \text { Bosnia \& Herzeg. } & 9892 & 3.51 \\ \text { Cyprus } & 3708 & 1.32 \\ \text { Egypt } & 3061 & 1.09 \\ \text { Fiji } & 5772 & 2.05 \\ \text { India } & 2819 & 1.00 \\ \text { Indonesia } & 8087 & 2.87 \\ \text { Iran } & 6353 & 2.26 \\ \text { Iraq } & 7749 & 2.75 \\ \text { Jordan } & 1348 & 0.48 \\ \text { Kuwait } & 1610 & 0.57 \\ \text { Lebanon } & 29321 & 10.41 \\ \text { Malaysia } & 2975 & 1.06 \\ \text { N-W Europe } & 2668 & 0.95 \\ \text { Pakistan } & 9238 & 3.28 \\ \text { Singapore } & 2091 & 0.74 \\ \text { Somalia } & 3585 & 1.27 \\ \text { Syria } & 2261 & 0.80 \\ \text { Turkey } & 23479 & 8.34 \\ \text { Sub-total } & 246102 & 87.4 \\ \text { All } & & 281576 \\ \text { Source } & & \end{array}$

Source: (DIMIA, 2003)

The Lebanese community was predominantly Christian (Maronite, Melkite and Catholic) until the 1960s. The early Muslim arrivals were Sunnis from northern Lebanon, around Tripoli, who settled in Canterbury in Sydney's inner west. They established the first mosque in Lakemba in the early 1960s. By 1971, about one in seven Lebanese-born residents were Muslims (3500), five years later, one in five (6500), by 1981, one in three (16000), by 1996, two in five (27000), and by 2001, slightly more than that (29300). In the period 1975 to 1977, some 14000 Lebanese arrived in Australia from the civil war, being admitted as immigrants rather than as refugees. Nearly three quarters of Muslim Lebanese live in Sydney.

Michael Humphrey, one of Australia's leading scholars on Lebanese Muslims, has argued that this form of entry for people traumatised and unsettled by war, threw them onto their own resources with little in the way of government or refugee welfare support (Humphrey, 2001). They had to establish their own institutions and networks, and develop strategies to cope with the inflow of people fleeing zones of conflict - particularly Shi'a from southern Lebanon and Beirut. The communities were poorly educated and had limited skills. They often faced unemployment on arrival, a situation compounded for the next generation. Sunni women had an even lower likelihood of working (more conservative religious practices, larger families) than Shi'a (11 per cent to 30 per cent; Humphrey, 2001). 
While Sunnis still make up about two-thirds of Lebanese Muslims and dominate religious organisations, some of the major political and social organisations are drawn from the Shi'a population - such as Amal and Hizbollah (the military wing of which is outlawed in Australia). Humphrey points out that the processes of immigration confront parents with significant problems of authority and influence over children (Humphrey, 2001), especially where there is institutional criticism of Australian social values, as there has been by the Mufti of Australia: 'The dangers threatening the Muslim community emanate from the law that prohibits the family's guardianship over its sons from the moment they reach the age of 16. The father has no authority over his son or his daughter...' (M.E.M.R.I., 2004). Muslim communities have become caught up in global and local cultural processes that intensify the differences between ethnic groups in Australia, and sharpen debates around the points of apparent distinctiveness.

\section{Discourses of difference - Muslims as Subjects or Objects?}

A central problem for an Australian political Islam remains its capacity to position Muslims as subjects in the narrative of Australia, rather than as objects of discussion or hostility. The complexities have been magnified by the rise of global terrorist groups espousing radical and expansionary forms of Islam, sometimes described as 'Islamist' ideologies. An increasing level of alarm and fear has characterised the wider community in Australia (as elsewhere in the West). In addition, there have been very specific local issues - some national, some citybased - that have made being Muslim in Australia rather more problematic than simply expressing the desire for religious tolerance and economic opportunity.

These local issues fall into two groups - those that reflect the presence of Muslim communities settling into Australian society, and those that reflect the margins of Muslims involved in transgressive or criminal activity. The first group includes the pressure by local Muslim communities to establish places of worship in previously Christian neighbourhoods; the request that public facilities introduce access regimes that would facilitate the participation by Muslim women (e.g. single sex use of swimming baths); and the spread of veiling as Islamic consciousness grows among young women. The second rather more dramatic element includes the high proportion of Muslims amongst asylum seekers and the allegations of 'illegality' and 'queue jumping' that are laid against them (Mares, 2001); the growth of criminal gangs involved in drugs and violent crime; and the most volatile, the cases of young Muslim men convicted for rape in which anti-Australian racial epithets were used to justify the attacks. The London bombings, with their vision of 'home-grown' terrorists, have magnified societal anxiety.

Each of these issues has stimulated on-going media attention, and in particular has attracted the interest of a network of neo-conservative media commentators whose rhetorical engagements with Islam have heightened tensions. They have been successful in adding fuel to the continuing discourses of exclusion that have been mobilised against Muslims over the past centuries in Australia.

In his examinations of anti-Muslim racism , and the specific dynamics around local conflicts over mosques, social geographer Kevin Dunn has proposed that there exists an over-arching discourse of 'Othering', whereby Muslims have been, and continue to be, subordinated and marginalised in Australia (Dunn, 2001; 2003; 2003a). His overall argument reflects the theoretical and empirical work by Ghassan Hage on the structures of Whiteness in Australia, and the 'paranoid' components of Australian nationalism (Hage, 1998; 2002). 
Muslims, Dunn suggests, represent a threatening and unwanted challenge to White Australian society. Australians see them as perpetrators of chaotic violence and carriers of very different ideologies of self. He traces this antipathy back to the establishment of Australia, and notes various points where Muslims have been seen or named as standing outside the circle of trustworthy citizenship.

Three critical dimensions of disagreement between Muslims and local communities emerge from his study - the impact of communal gatherings of 'Others' on the quiet enjoyment of neighbourhood by the non- Muslim society; the Otherness of Muslims and their cultural practices; and the supposed untrustworthiness of Muslims and their tendencies to avoid statutory obligations and rules.

Demonisation dominates the public conversations about Australian Islam. Critical narratives are publicly presented by a small group of conservative media commentators and linked political figures. The two most critical elements relate to criminal gangs and militant Islamist religious groups - and they are critical because they both relate to 'real' behaviour, and they contribute to the creation of what Arabic Council leader Joseph Wakim has called the 'secondary victims of terrorism'(Wakim, 1999).

\section{Demonisation}

Through the first years of the new millennium, Sydneysiders were shocked by the rise of violent crime and a series of gunshot murders in the southwest of the city. The media accounts pointed to a small number of networks of families of Lebanese Muslim origin who were struggling for control of a variety of criminal activities - car theft, ram raids, drug dealing and extortion. The evening news reports would show small suburban houses peppered with bullet holes, bodies slumped under arc lights in pools of blood, and dour faced police talking about crime waves, while women in hijabs wept quietly by the roadside or uttered heart-rending screams of grief and anger.

The most well-known of the radio commentators, Alan Jones, had made numerous critical comments about Muslims, not only in relation to such crime events. Jones has been identified as a major player by the NSW state Anti-Discrimination Board which, in its report Race for the Headlines, argued that Jones was a sustained contributor in terms of 'those who seek to isolate the minority experience so that it can be explored and exposed' (Anti-Discrimination Board of NSW, 2003). The report noted numerous examples of the discourses that Jones mobilised to communicate his feelings, most focussed on the idea that White Australians were losing their rights to Muslims who were supposedly unwilling to adopt Australian customs. His clearest views can be summarised in this own words: 'it is important to respond to the high level of public concern over the risk that such ideas pose to the Australian way of life. We are a multi-racial society, not a multi-cultural society. The dominant culture is the Australian culture.' (Jones 2GB, 16 October 2003). Jones was later to be implicated as an active supporter of attacks by Anglo-Australian youths on Lebanese Australians in Cronulla, in December 2005.

\section{Political Islam in the Australian polity}

Muslim communities of Australia are caught in a 'radical social uncertainty' associated with occasional outbursts of 'bodily brutality' (Appadurai, 1999, p. 306). This uncertainty refers 
not only the 'Other', but also to 'a deep and dramatic uncertainty about the ethnic self' (Appadurai, 1999, p.322). The Muslim communities and the Australian polity are thus confronted with a common critical task - how to reduce the uncertainty for both that will otherwise intensify the tensions and alienation apparent amongst Australian Muslims. Governments have engaged with these tensions by promoting inter-faith dialogues, importing moderate Muslim scholars to preach and lecture, and looking for ways of 'calming' points of potential conflict. Within the Lebanese Muslim community, a program continues to reconnect alienated and potentially violent young men back into communal institutions, and to ensure that other young people by-pass the attractions of criminality and gang membership.

Michael Humphrey (2003) has argued that the situation is worsening for Muslims, as Australia opts for national security in the context of concerns about global security.

In this process, Australia's Muslims become the embodiment of the dangerous Others from outside the nation (Humphrey, 2003). Similarly Hage (2002; 2003) has pointed to the decaying quality of citizenship for Muslims, as they have become targeted by the internal security services as potential terrorists and threats to the nation as a whole (Hage, 2002; 2003).

Australia has been fundamentally transformed by Islam and the community of Muslims who are resident in the country. The vast majority of Muslims are serious, hard-working and often pious, drawn from many cultures and who feel marginalised by aspects of Australian society. Yet at the same time the new generation of educated middle class Australian Muslims seek to find a place that makes sense in Australian modernity.

As in many communities the dysfunctional edges produce angry and aggressive men, who offer themselves as the activists for criminal gangs or radical militaristic organisations. Their marginalisation can feed this anger, a position validated for them by Australia's alliance with the US in the war on terror. New organisations exist that can and do call on these people as protagonists in a new Australian Islamist politics, one where crime and politics align.

Muslims are drawn from a range of ethnic backgrounds - over 60 in Australia. The largest Muslim nation, Indonesia, is Australia's nearest Asian neighbour, while the largest single group of Muslims - from Lebanon - account for over one-third of the Muslim population, most of whom are located in Sydney. Many Australian Muslims sought out Australia for its values and opportunities, seeking an open and egalitarian society offering refuge and freedom, a place both to be a Muslim and be a free citizen of an open social order. Media accounts often focus on their disruptive and alien presence, while political engagements seek to normalise their presence and marginalise whatever deviant behaviour - gang violence, rape, drug running and theft - exists. Even so the dominating images are generated in response to a tiny part of the community (Saeed, 2003).

As with all communities there are many different perspectives. If communities are defined by their religious affiliations, then their public presence in the wider society will be mediated by discussions on those values associated with religious belief. Yet these communities have been affected by and have often sought the diversity that modernity provides, so that the assumptions of internal discipline and hierarchies of leaders and followers may be divorced from the complex realities that exist in the neighbourhoods of Australian cities and in the rural towns where many Muslims have settled. 
While this diversity of Islam allows for many tendencies, orientations and attitudes to religious and community life, it is helpful to focus on the longer established and most publicly discussed segments of the community, for they allow a testing of the wider perceptions of Islam against a more systematic examination of the issues as community leaders perceive them. In this case, I want to explore the Lebanese Muslim Association - based near the Lakemba mosque in Sydney, an organization run by the community's male leaders, and the trans-ethnic Muslim Women's Association, located near-by but with a wider sense of its communal leadership responsibilities.

\section{From the patriarchy: political Islam}

At the time of the interview with him in mid-2004, Kayser Trad, was director of the Lebanese Muslim Association. By mid-2005, he had lost that role in an internal change in the structure of the LMA committee, possibly spear-headed by more fundamentalist local clerics in an alliance with younger professionals, some with links to the conservative Liberal Party: Trad had been more closely associated with the Australian Labor Party. Trad is an articulate and Australian-educated spokesperson for his community, and de facto, a major media presence who is sought out to represent all Muslims in Sydney (and more widely). He has been the 'minder' and English voice for the most well-known and controversial imam of the Lakemba mosque, Sheik Al-Hilaly, whose role as Mufti of Australia has been highly controversial. After his loss of the LMA role Trad established the Islamic Friendship Association of Australia.

Trad identified five of the most important issues that were confronting his imam's 'political Islam', and how they might be addressed. The issues began with the very immediate problem of defending the LMA against takeovers from more militant Muslim groups, then how to engage with inter-generational relationships, moving to conflicts with the state and national governments, and then turning to the local implications of global tendencies in Islam.

Our conversation took place on a busy Friday after midday prayers. Trad, at the time, was locked into the increasingly testing struggle for control of the LMA, engineered by non-LMA local imams who were drafting young men into membership of the Association as a prelude to an election later in the year, an election that Trad survived, only to lose out he following year. That morning, Trad had found half a raw pig's head dumped on his car outside his house, and detectives were on their way. He was half sure the culprits were those who felt that Trad and the Mufti were insufficiently rigorous in their Islamic beliefs and practices. At midday, a visiting British Islamic scholar addressed the service of some 3000 men and a few hundred women, in fair Arabic (according to Trad) and in the rolling tones of Cambridge English. His sermon focussed on personal responsibility and the trap of only blaming others for our own difficulties. Our interview was interspersed with Trad's conversations on his cellphone to Iraqi Shi'ites in Bankstown seeking his advice on how to organise a demonstration over American and Australian attacks on Shi'a communities in Iraq, and across the table with an Indian imam from Brisbane seeking advice on how to manage land required for a mosque and community hall there.

The first issue raised by Trad concerned the legal status and security of his own association in the face of attempts at takeovers. Any Lebanese Muslim adult male could join the LMA and while Australian not-for-profit company law protects members, the board of the association can trade in its assets, hive them off, and so forth. Trad was concerned that the attempts at taking over the LMA could undermine and destroy the organization and the community it 
serves. He was therefore looking for a legal form that might protect the assets and retain them within the community. In that regard he was exploring how the wakaf under Islamic Law (a form of donation or grant for communal purposes) could be instituted in Australia:

Wakaf...signifies the dedication or consecration of property either in express terms or by implication for any charitable or religious objects to secure any benefit to human beings ... 'wakaf am' means a dedication in perpetuity of the capital and income of property for religious or charitable purposes recognised by Islamic law, and includes the property so dedicated. (George, 2001).

Here was an attempt to find in Islamic law an option that would protect a religious institution from behaviour that would normally be permitted for secular organizations, and to discover how this might be given form in Australian secular law. It could not be done, as he discovered.

In relation to the goals of political Islam in Australia, Trad was clear that the most central issue lay at the point where religion and society intersected, on the question of the transmission of values to the next generation. It was as though he were echoing concerns of mainstream non-Muslim conservative politicians, that the younger generation was being allowed to escape the disciplines of a practical ethics necessary for the modern age. The breakdown of order could be found in the failure of schools to ensure adequate values education, and the tendency of the law to separate adolescents from the moral authority of their parents. His concern was generated by a range of issues, ranging from the public debate about Muslim young men involved in rape and violence, to the gravitation towards more austere and fundamentalist forms of Islam. Trad was looking for a form of ethics education that would encompass the traditional hierarchy of family loyalty and respect for parental wishes, the development of an ethics of human rights appropriate to a pluralist society, and the promotion of a process of respect for the peaceful resolution of social differences.

The third goal he identified concerned the way in which the wider society perceives and labels Muslims. Trad argued that the labelling of criminals with 'ethnic' markers such as 'of Middle East appearance' generates suspicion and hostility in the wider society, and a defensive anger among young men within the Muslim communities. Ethnic markers are not used, he argued, when talking of crimes by Anglo-Australians. The latter is particularly important as the growth of deep-seated resentment and alienation from the broader value system of society can only have negative and potentially violent effects, a situation exemplified by local Lebanese youth who explore their alienation from Australian society (Collins, Noble et al., 2002). This issue has divided the Muslim and other Middle Eastern communities internally, especially given approach of the New South Wales state government and its aggressive then premier Bob Carr, who had vigorously defended ethnic descriptors in the past. Moreover Trad argued that the sustained media antipathy to Muslims corrodes social relations more widely and undermines Australian democracy.

At this point international issues intruded. Trad indicated that he was upset about the way in which Australian politicians expressed views he described as 'biased' in relation to international events. In particular, he argued that bias was shown in support for Israel against the Palestinians, and support for the USA against Muslims - especially Arabs. The tortuous war in Iraq had exacerbated these perceptions, with Australian politicians such as the Prime Minister John Howard being seen as 'unbalanced' in his approach. In Trad's view, politicians should represent the diversity of views in Australian society - Muslims have a legitimate 
point of view on international questions and these views appear to be disregarded in the national arena. One goal of political Islam is to move Australian politicians to a more 'balanced' position - perhaps including support for a one-state Palestine solution and a withdrawal from the close alliance with the USA and its perceived anti-Islamic position.

These various dimensions of political Islam coalesce around the clash between radical and fundamentalist Islam, and the wider Muslim world. Trad identified with traditional but not fundamentalist Islam. He noted that there were pressures on the LMA and therefore on his view of political Islam and these came from two sources - a fundamentalist Wahabi group effectively backed by Saudi Arabia under the umbrella title of Ahl as-Sunnah wal Jama'ah; and a self-described moderate force of Sunnis (with its headquarters in Pittsburgh in the USA) operating under the title of the Association for Islamic Charitable Projects (based close-by in Bankstown). The AICP ran the Spears Sports Club and the Al Amanah private school - the latter with two campuses in Bankstown and Liverpool.

These organizations had been variously fencing for position and authority within the Lebanese and associated Sunni communities, and they increasingly dominated the practical politics of Australian Islam. Trad had blamed AICP for providing information on a Wahabist group, the Islamic Youth Movement (publisher of Nida'ul Islam) to ASIO (Australian security service), triggering ASIO raids on the IYM following the 9/11 bombings, a payback for conflict over a community radio licence. In late 2004, the AICP launched a new organization, claiming a status as the High Council of Islam in Australia, a direct challenge to the Australian Federation of Islamic Councils, the source of Hilaly's status as Mufti. Meanwhile, the new LMA leadership were not invited to the Prime Minister's August 2005 meeting of Islamic leaders, though Hilaly was invited. He arranged not to attend by remaining overseas.

\section{Women and political Islam}

Muslim women set rather different priorities and reflect a deeper sense of the developmental dynamics required compared to the rather more public politics associated with maledominated groups. Women have had to deal more directly in the everyday with the contradictions that modernity generates for Muslim communities. In part, their aspirations, legitimated by their readings of the Qur'an and the Sunnas, are expressed in their desire for higher education and careers, and for more dynamic engagement with the wider society. If veiled, they are the more visible presence of Islam and they are thus the targets of racism, anti-Muslim sentiment and public antipathies.

Maha Abdo, executive officer of the Muslim Women's Association, responded to my queries about the five most important goals for the community, and in particular, for women. Abdo has been an activist in the organization for nearly two decades, and comes from a Lebanese family that arrived in the early days of post-war settlement. During the 1970s, as the wave of multiculturalism and community development washed through immigrant communities, and as the early issues of settlement become clearer, Muslim women from many national backgrounds began meeting informally to exchange views, identify directions for action and explore strategies. In 1983, the MWA was formed, its early activists including women from Lebanon as the major group, but also women from Turkey, Singapore, Egypt and other Muslim countries. The MWA was set up during the period of major upheaval at the Lakemba mosque in the wake of Sheik Hilaly's arrival. Hilaly gave support to the women; he accepted that they needed to be independent and to focus on issues particularly concerning women, 
ranging from domestic violence to educational opportunities for girls to employment and career paths.

The women saw themselves as more 'ahead' than the men, partly because many of the women leaders were tertiary educated and also because women had to deal with the wider Australian society, for instance, through their children's contacts at school. During the Hawke-Keating governments (1983-1996), the MWA grew in strength and influence, joining the Australian Federation of Islamic Councils, and sponsoring new women's groups around the country. In 1988, it set up the Muslim Women's Support Centre, providing domestic violence and emergency accommodation services, and using Islamic teachings as a basis for drawing men into a recognition of their responsibilities and the prohibition on violence (Sun Herald, 6 May 1990). During the first Gulf War, the MWA publicised attacks on Muslim women, reporting that they were getting fifteen calls a week from women who had been abused in public areas (Sunday Morning Herald, 14 January 1991).

During the following decade MWA became an embedded element in the Muslim communities and, as importantly, a critical interface between the wider social structure and those communities. The Association developed more child-care centres, programs for women experiencing domestic violence, women's refuges and half-way houses, and a multitude of counselling and support services, and by 2004, had been contracted by government to provide a number of services to non-Muslim women, using Islamic alternative dispute resolution strategies. With the resurgent Intifada in Palestine and other issues emerging - and then the events of 9/11 - the community and its women felt themselves in the firing line.

In the face of these conflicts, the women's movement in the communities has had to develop a clearer sense of how it will move forward, in the face of internal fundamentalisms and external racism. For Maha Abdo, the five goals (some fleshed out in the 2001 MWA Future Directions Plan 2002-2007, supported by the NSW Department of Women) began with the most critical issue - how to have rational debates within the Muslim community and resolve issues there, before taking the debate outside, and how to become more inclusive and involve non-Muslims in the processes of dialogue. Many of the issues to be resolved arise from the experience of the thousands of MWA clients over two decades; these include arranged marriages, domestic violence and education for girls, in which the Qur'an supports women's rights but local village cultures in countries of origin may not. One direction that has been taken is to have the Mufti reflect on these questions (in a positive way) during his sermons.

The second goal addresses the wider participation by Muslim women in the power structures of Australia - on management committees of community organizations, on government advisory boards, and in political roles. Leadership development has become a major dimension of MWA work, not only in the camps and mentoring processes, but also in areas such as media workshops and skill development.

The third goal focuses on guarantees for religious freedom. Many Muslim women have become acutely aware of the way in which ostensibly free societies can take action in the name of equality that can undermine religious freedom, as in France with the ban on hijab wearing in schools. Whereas Victoria had legislated to protect religious beliefs, Muslims were still only protected under their ethno-religious dimension in NSW and other states. Such situations require a political Islam more unified and strategic, able to influence governments in a sustained way. 
Public awareness of the contributions of Muslims is also needed. One way of achieving such progress would be through the more regular recognition of the successes of young Muslims in the media and in government. MWA would also like to see a more sustained and regular research program into the needs of Muslim communities, and the incorporation of such needs into policy proposals. Participatory research that would involve community members, build community skills and provide a solid information base for long term strategies, has become an essential component of the longer term view.

The gender relations within the Muslim communities are of major concern to all the leaders Abdo was distressed that Muslim women were now perceived in the wider community not as peaceful contributors and family members, but as the mothers of rapists who would hide Kalashnikov guns under their burkhas (a reference to comments by Christian politician Rev Fred Nile and conservative politician John Stone about Muslim women). Outreach, education and interaction now feature in MWA strategies, most clearly realised in the magazine and website Reflections (http://reflections.org.au) which is supported by MWA and written by young Muslim women.

\section{Governmentality and Australian Muslims}

Many of these dynamics reached a crescendo around the summit of Muslim leaders organised by the Australian Prime Minister in August 2005. The goal of the summit, to lock in 'moderate leaders' around a shared condemnation of terrorism, had the additional effect of forcing those not invited to the event to band together in criticism of the process.

Opening the summit, PM John Howard focussed his comments on the issues of terrorism:

There are a number of people in our community who are a danger to all of us, not many but some, and we have an obligation to try and identify them, to neutralise them, to prevent them influencing others particularly the young, particularly the young, and in the process learn from the experience of working together effectively as Australians. But my starting point is that we come together as Australians with an overriding loyalty to the future of this country and to nothing else and that we will work together as Australians with that overriding loyalty to try and prevent problems that have occurred in other countries (J Howard, MP 23 August 2005).

Ameer Ali, President of the Australian Federation of Islamic Councils, the body selected by the government to 'broker' participation in the Summit, noted that this was the first time government had ever met with Muslim communities, despite decades of discrimination and communal anxiety. One might infer that it was only the fear of violence and terror that could have brought about such a desire in government for what the PM had called 'a continuing dialogue'.

Other Muslims were highly critical of the AFIC role, arguing as did Amir Butler (The Age 23 August 2005) that:

Despite Government claims, the composition of this meeting is not reflective of the broader community and those attending hold no mandate to either make decisions on behalf of the community or to represent their views. 
The highly fragmented Muslim communities outside the Summit - stressed along lines of national origin, religious sect, political orientation and generation - made accusations against each other. Some were described as extremist, others as fundamentalist, others as out-of-touch or 'dinosaurs', others as collaborators with an anti-Muslim government. However, on September 11 2005, many of these groups were able to meet in a National Security and Harmony Summit of their own around a shared concern that Muslims should be able to participate as other Australians in the political processes of their society.

While the government embarked on a sustained campaign to 'connect' with the diversity of Australian Islam (Multicultural Affairs Minister John Cobb announced on September 162005 an advisory committee of similar people to those who had participated in the August summit), a number of new interventions by government ministers fuelled both Australia-wide alarm and anxiety within the Muslim communities.

Deputy Liberal Party leader, and PM aspirant Peter Costello, picking up on the rhetoric but perhaps not the politics of the Prime Minister's summit, proposed that:

'If you don't like those values, then don't come here. Australia is not for you.... 'This is the way I look at it: Australia is a secular society, with parliamentary law, part of the Western tradition of individual rights.' In an interview with The Australian, Mr Costello said migrants needed to understand and respect the 'core values' of democracy, a secular society and the equality of women. And he warned that Australia needed to be clear that the nation's core values would not change. .... Foreign Minister Alexander Downer also compared fundamentalist Muslims to Nazis ..... (The Australian, 24 August 2005).

Another contender for the PM's position. Education Minister Brendan Nelson, announcing a plan to police the curricula in Muslim schools, also entered the fray, under the headline 'AntiAussie Muslims should go'.

Muslims in Australia who don't want to accept local values should leave the country, Federal Education Minister Brendan Nelson said today. Muslim schools will have to denounce terrorism as part of an effort to stamp out home-grown extremism, under measures announced yesterday following a meeting between .... He said all Australian schools were required to teach the national values framework, including tolerance, responsibility and understanding, to students. People who were not prepared to follow these Australian values should 'clear off', he said. (Australian Associated Press, 24 August 2005).

\section{Conclusion: a multicultural future?}

These engagements with the presence of proponents and opponents of radical Islam in Australia have highlighted the serious questions that now lie exposed in the debates about multiculturalism. In essence they demonstrate that the possibility of a multicultural polity rests on the shared acceptance of core values as enunciated by the dominant community's leaders, and as manifested in the social practices of that polity. The boundaries are firmly set, with the degrees of tolerance of diversity being those acceptable to the more powerful elements in the dominant social structure. 
Three sets of overlapping events have intensified the controversial location of political Islam in the Australian political landscape. Following the passing of new anti-terrorism laws, police arrested some 19 alleged Islamic militants in Sydney and Melbourne in November 2005, charging them with conspiracy to commit terrorist offences; police claimed they were followers of Osama bin Laden, and were led by a local Wahabi Islamic cleric. In December 2005, a "White riot" against Muslims erupted at the Sydney seaside suburb of Cronulla, where 5,000 non-Muslims turned on a few visiting Muslim youth in a well co-ordinated attack organised through text messages and radio talk-back encouragement. Over the following two days retaliatory raids by young Muslim men occurred in the neighbouring suburbs. Australia was horrified, and governments began to identify more direct strategies of intervention in "inter faith dialogue' and "inter-cultural understanding” (Hartley and Green, 2006; Poynting, 2006)..

Then throughout 2006 and 2007 media attention was focused on Sheik Al Hilaly for his political and cultural comments. He had been quoted as supporting Hizbollah against the Israelis, as criticising Anglo Australians as being the descendants of criminals, and of Australian women displaying themselves "like meat for cats", responsible therefore for their own rapes. Hilaly was under increasing pressure from the media, some parts of the Muslim community and the government, to resign his position as "Mufti" (a role to which he had been appointed in the 1980s by AFIC). By early 2007 a gathering of imams had formed a national council, and had resolved eventually to dissolve the position of Mufti, which they felt was not relevant for Australia. In the interim they appointed the elderly Sheik Fehmi of Melbourne to replace Hilaly, who had resigned on health grounds.

In ways probably not previously apparent, the dynamics of internal multiculturalism are now shaped by the global geo-politics in which the Australian government is now engaged. Muslim communities which are seeking to make a place within the non-Muslim polity, are confronted by two pressures. On the one hand, there are the very public demands that they conform to 'core values', espoused as they are by a conservative government firmly committed to Anglo-Australian narratives of the nation. In these narratives, multiculturalism plays a minor part and where acknowledged, symbolises the traditions of an Anglo-Saxon tolerance of minorities. Indeed cultural diversity has been suppressed as a core value, to be replaced by a new unitary rhetoric of citizenship.

On the other hand, the promise of multiculturalism has led the thousands of members of the Muslim communities to believe that they have rights to follow their own cultural mores, and to use the freedom of Australia to build new and more open social relations. In the granularity of the every-day, their lives express this reality. In dozens of schools, they try to develop an Islamic modern morality, while defending Australia against the criticisms of the extremists for whom any western modernity is anathema.

This contemporary crisis in the presence of Muslims in Australia draws out all the main contradictions of liberal multiculturalism. The political management of this crisis has reached an important point, and the decisions for all parties are framed by their understanding of what is involved in reciprocity in social relations. It can either intensify the problems and thereby potentially trigger an active withdrawal across the board from any acceptance of cultural pluralism, or it can force a re-assessment of multiculturalism so that it re-emerges as a dialogue of negotiation between cultural communities rather than a set of instructions handed down to minorities. 


\section{References}

Anti-Discrimination Board of NSW (2003). Race for the headlines. Sydney: ADB of NSW. Appadurai, A. (1999). Dead certainty: Ethnic violence in the era of globalization. In M.B. and P. Geschiere (Eds.) Globalization and Identity: dialectics of flow and closure. pp. 305324. Oxford: Blackwell.

Collins, J., Noble, G., et al. (2002). Kebabs, kids, cops and crime: Ethnicity, youth and crime. Sydney: Pluto Press.

DIMIA (2003). The people of Australia: statistics from the 2001 Census. Canberra: Department of Immigration and Multicultural and Indigenous Affairs.

Dunn, K. (2001). Representations of Islam in the politics of mosque development in Sydney. Tijdschrift voor Economische en Sociale Geografie, 92(3): 291-308.

Dunn, K. (2003). Racism in Australia: findings of a survey on racist attitudes and experiences of racism. Paper to the Challenges of Immigration and Integration in the European Union and Australia, National Europe Centre.

Dunn, K. (2003a). Representations of Islam in Australia. Research Institute for Asia and the Pacific Diversity of Islam Seminar Series, No.2, The Education Building, The University of Sydney.

George, M. (2001). An Overview of Issues in Charity Litigation in Malaysia. The International Journal of Not-for-Profit Law vol 4, no 1. Retrieved 11 Apr, 2004, from http://www.icnl.org/journal/vol4iss1/george8.htm

Hage, G. (1998). White nation : fantasies of white supremacy in a multicultural society. Sydney: Pluto Press.

Hage, G., (Ed.) (2002). Arab-Australians today : citizenship and belonging. Carlton South, Vic.: Melbourne University Press.

Hage, G. (2003). Against paranoid nationalism: Searching for hope in a shrinking society. Sydney: Pluto/Merlin.

Hartley, J., \& Green, J. (2006). The public sphere on the beach. European Journal of Cultural Studies, 9(3), 341-362.

Humphrey, M. (2001). Muslim Lebanese. In J. Jupp (Ed.), The Australian People. pp. 564567. Cambridge: Cambridge University Press.

Humphrey, M. (2003). Australian Islam, the New global terrorism and the limits of citizenship. Islam and the West: the Impact of September 11. 15-16 August(Monash University and the University of Western Australia).

Jakubowicz, A. (2005). "Religion and Australian Cultural Diversity”, Canadian Diversity, Fall, 51-55.

Jakubowicz, A. (2006). "Anglo-multiculturalism: Contradictions in the politics of cultural diversity as risk”, International Journal of Media and Cultural Politics, 2 (3), 249-266

Jones, M. L. and Museum of Victoria (1993). An Australian pilgrimage : Muslims in Australia from the seventeenth century to the present. Melbourne: Victoria Press in association with the Museum of Victoria.

M.E.M.R.I. (2004). The Mufti of Australia Calls for Jihad; 'Australia was Discovered by Afghan Muslims', The Middle East Media Research Institute (Berlin) trans. from $<$ Islam.web>.

Mares, P. (2001). Borderline: Australia's treatment of refugees and asylum seekers. Sydney: UNSW Press. 
Nebhan, K. (1999). Identifications: Between nationalistic 'cells' and an Australian Muslim Ummah. Australian Journal of Social Issues, 34(4), 371-385.

Hartley, J., \& Green, J. (2006). The public sphere on the beach. European Journal of Cultural Studies, 9(3), 341-362.

Saeed, A. (2003). Islam in Australia. Sydney: Allen and Unwin.

Saeed, A. (Ed.) (2001). Muslim communities in Australia. Sydney: UNSW Press.

Wakim, J. (1999). Guilty until proven innocent. Restoration for Victims of Crime Conference, Melbourne, Australian Institute of Criminology in conjunction with Victims Referral and Assistance Service. 